\title{
Perancangan Sistem Deteksi Dini Lift Barang Berbasis Arduino di PT Dharma Electrindo Manufacturing
}

\author{
Maharani Ongky Anggraini and Antonius Suhartomo \\ Study Program of Electrical Engineering, President University, Bekasi 17550, Indonesia \\ Corresponding author: asuharto@president.ac.id
}

\begin{abstract}
PT Dharma Electrindo Manufacturing is one of the compant in automotive manufacture. This company has two plants which are in Cikarang and Cirebon, with Cirebon focusing on the manufacturing side. PT Dharma Electrindo Manufacturing Cirebon branch has three floors for production. Thus it is necessary to have a freight elevator to ease production process on second and third floor with support from AGV (Automatic Guided Vehicle) with the market price of Rp 200.000.000 without humans directly controlling it. Several accidents could happen due to unsynchronized elevator door and AGV. In 2017, 15 accidents occurred on the elevator door on the second floor. Because of this, an early detection system has been implemented in the form of a crossbar on the door such that the AGV does not hit the acrelyte-made door which could cause the AGV to fall and caused the company loss about $R p 200.000 .000$ or the broken elevator door all through 2017 which caused Rp 202.250.000 loss. It is hoped that this crossbar implementation is developed using stabilizer.
\end{abstract}

Keywords: early detection system, elevator crossbar, freight elevator, synchronization, AGV, RFID, stabilizer.

\begin{abstract}
ABSTRAK
PT Dharma Electrindo Manufacturing merupakan salah satu perusahaan yang bergerak dalam bidang manufaktur otomotif. PT Dharma Electrindo Manufacturing memiliki 2 plant yaitu di Cikarang dan Cirebon, namun proses manufaktur berada di Cirebon. PT Dharma Electrindo Manufacturing di Cirebon memiliki 3 lantai yang digunakan untuk proses produksi. Untuk itu dibutuhkan lift barang agar dapat mempermudah proses produksi untuk lantai 2 dan 3 dengan dukungan AGV (Automatic Guided Vehicles) seharga kurang lebih Rp 200.000.000 sebagai sarana untuk mengantarkan barang - barang produksi yang telah sinkron dengan kinerja lift barang secara otomatis tanpa bantuan manusia lagi. Terjadinya kecelakaan kerja yang di karenakan tidak sinkronnya antara pintu lift dan AGV. Sebanyak 15 kali kecelakaan sepanjang tahun 2017 untuk pintu lift lantai 2. Oleh karena itu, dibuatlah perancangan sistem deteksi dini yaitu palang pintu lift agar AGV tidak menabrak pintu lift yang hanya terbuat dari akrelit dan menyebabkan AGV jatuh yang akan merugikan perusahaan kurang lebih Rp 200.000.000 atau pintu lift rusak yang sepanjang tahun 2017 mengeluarkan biaya Rp 2.250.000. Setelah dibuatkan palang pintu lift ini maka akan menghilangkan kerugian sebesar Rp 202.250.000. Harapan untuk pengembangan teknologi palang pintu lift ini dengan menggunakan stabilizer.
\end{abstract}

Kata kunci: sistem deteksi dini, palang lift, lift barang, sinkronisasi, AGV, RFID, stabilizer.

\section{PENDAHULUAN}

Seiring dengan perkembangan ilmu pengetahuan dan teknologi yang senantiasa menuntut efisiensi yang tinggi dan teknologi tepat guna khususnya dalam ilmu elektronika, maka semakin banyak aplikasi-aplikasi yang sebelumnya sangat sulit dikerjakan oleh manusia menjadi lebih mudah, lebih cepat dan lebih teliti terutama untuk perusahaan - perusahaan padat karya.

Di era globalisasi dimana pertumbuhan ekonomi Indonesia menuntut perusahaan-perusahaan manufacturing untuk melakukan efisiensi di setiap proses kerjanya mengakibatkan semakin banyaknya hal-hal yang harus dipenuhi oleh PT Dharma Electrindo Manufacturing agar dapat tetap bersaing. Dalam hal ini, PT Dharma Electrindo Manufacturing menggunakan AGV dan lift barang sebagai sarana untuk proses produksinya. Namun dalam proses penggunaan $\mathrm{AGV}$ dan lift barang ini, ada kejadian abnormality atau error pada sistem yang berpotensi mengakibatkan perusahaan kehilangan asset yaitu kerusakan $\mathrm{AGV}$ atau jatuhnya $\mathrm{AGV}$ dari lantai 2 ataupun 3, dimana harga AGV ini sendiri kurang lebih 200 juta rupiah, seperti yang didaftarkan dalam data frekuensi kejadian dan kerugian perusahaan (Tabel 1).

Tabel 1. Frekuensi Kejadian dan Kerugian Masalah Karena AGV

\begin{tabular}{|c|c|c|c|c|}
\hline No & Kejadian & $\begin{array}{c}\text { Frekuensi } \\
2017\end{array}$ & Kerugian & Total Kerugian \\
\hline 1 & $\begin{array}{c}\text { AGV tidak } \\
\text { mau masuk } \\
\text { lift }\end{array}$ & 6 & $\mathrm{Rp} \mathrm{-}$ & $\mathrm{Rp} \mathrm{-}$ \\
\hline
\end{tabular}




\begin{tabular}{|c|c|c|c|c|}
\hline 2 & $\begin{array}{c}\text { AGV } \\
\text { menabrak } \\
\text { pintu lift } \\
\text { lantai 2 }\end{array}$ & 15 & Rp 150.000 & Rp 2.250.000 \\
\hline 3 & $\begin{array}{c}\text { AGV } \\
\text { menabrak } \\
\text { pintu lift } \\
\text { lantai 3 }\end{array}$ & 9 & Rp 150.000 & Rp 1.350.000 \\
\hline 4 & $\begin{array}{c}\text { AGV tidak } \\
\text { berhenti di } \\
\text { stasion }\end{array}$ & 2 & $\mathrm{Rp} \mathrm{-}$ & $\mathrm{Rp}-$ \\
\hline 5 & Salah rute & 7 & $\mathrm{Rp}-$ & $\mathrm{Rp}$ \\
\hline
\end{tabular}

Abnormality tersebutlah yang memicu penulis untuk membuat sistem keamanan untuk menjamin asset perusahaan. Sistem keamanan yang direncanakan merupakan sistem keamanan yang memungkinkan untuk mendeteksi secara dini berupa palang pintu lift yang digunakan di PT Dharma Electrindo Manufacturing. Dengan adanya sistem deteksi dini ini, PT Dharma Electrindo Manufacturing tidak akan mengalami kerugian atas kehilangan asset perusahaan.

\section{LANDASAN TEORI}

\section{A. Hardware}

\section{1) Limit Switch}

Limit switch merupakan jenis saklar yang dilengkapi dengan katup yang berfungsi menggantikan tombol. Prinsip kerja limit switch sama seperti saklar Push ON yaitu hanya akan menghubung pada saat katupnya ditekan pada batas penekanan tertentu yang telah ditentukan dan akan memutus saat katup tidak ditekan. Limit switch termasuk dalam kategori sensor mekanis yaitu sensor yang akan memberikan perubahan elektrik saat terjadi perubahan mekanik pada sensor tersebut. Penerapan dari limit switch adalah sebagai sensor posisi suatu benda (objek) yang bergerak.

Limit switch umumnya digunakan untuk memutuskan dan menghubungkan rangkaian menggunakan objek atau benda lain, menghidupkan daya yang besar, dengan sarana yang kecil. Sebagai sensor posisi atau kondisi suatu objek. Prinsip kerja limit switch diaktifkan dengan penekanan pada tombolnya pada batas/daerah yang telah ditentukan sebelumnya sehingga terjadi pemutusan atau penghubungan rangkaian dari rangkaian tersebut. Limit switch memiliki 2 kontak yaitu kontak NO (Normally Open) dan kontak NC (Normally Close) dimana salah satu kontak akan aktif jika tombolnya tertekan.

\section{2) Relay 2 Channel}

Relay adalah saklar yang dioperasikan secara elektrik yang memungkinkan untuk menghidupkan atau mematikan sirkuit menggunakan tegangan dan atau arus jauh lebih tinggi dari sebuah mikrokontroler bisa menangani. Tidak ada hubungan antara rangkaian tegangan rendah yang dioperasikan oleh arduino uno dan rangkaian daya tinggi. [1]
Relay 2 channel ini memerlukan arus sekurangkurangnya 15-20 mA untuk mengontrol masing-masing channel. Disertai dengan relay high-current sehingga dapat menghubungkan perangkat dengan AC $220 \mathrm{~V} \mathrm{10A}$. Jika menggunakan arduino uno dengan tegangan kerja $5 \mathrm{~V}$. [2]

Pada dasarnya, relay terdiri dari 4 komponen dasar yaitu:
a. Electromagnet (Coil)
b. Armature
c. Switch Contact Point (Saklar)
d. Spring

\section{Spesifikasi:}

- Jumlah relay $: 2$

- Sinyal kendali : TTL level (ACTIVE LOW)

- Catu daya : 10A - 250VAC, 10A - 30VDC, 10A 125VAC, 10A - 28VDC

- Contact action time : $10 \mathrm{~ms} / 5 \mathrm{~ms}$

- Indicator LED for each channel

- Relay size : $51 \times 41 \mathrm{~mm}$

- $\mathrm{VCC}: 5 \mathrm{~V} \mathrm{DC}$

- $\mathrm{COM}: 5 \mathrm{~V} \mathrm{DC}$

- IN1 : high/low output

- IN2 : high/low output

- GND : ground

Kontak Poin relay terdiri dari 2 jenis yaitu :

- Normally Close (NC) yaitu kondisi awal sebelum diaktifkan akan selalu berada di posisi CLOSE (tertutup)

- Normally Open (NO) yaitu kondisi awal sebelum diaktifkan akan selalu berada di posisi OPEN (terbuka).

Relay melindungi setiap rangkaian dari masing-masing rangkaian lain.

Setiap saluran di modul memiliki tiga koneksi bernama NC, COM, dan NO. Relay terdiri dari coil dan kontak coil adalah gulungan kawat yang mendapat arus listrik, sedangkan kontak adalah saklar yang pergerakannya tergantung dari ada dan tidaknya arus listrik pada coil. Relay memiliki batas kemampuan dalam mengalirkan arus listrik dan biasanya batas kemampuan relay ini tertulis pada fisik relay. Terdapat berbagai ukuran relay yang dipakai, semakin besar kemampuan relay mengalirkan arus listrik, biasanya bentuk dan ukuran fisiknya lebih besar. Produk yang digunakan dalam tugas akhir ini merupakan relay $5 \mathrm{~V}$ dengan 2 channel output. Dapat digunakan sebagai saklar elektronik untuk mengendalikan perangkat listrik yang memerlukan tegangan dan arus yang besar. Kompatible dengan semua mikrokontroler.

\section{3) Inverter}

Inverter merupakan sebuah alat yang terdiri dari rangkaian elektronika daya dan berfungsi untuk mengubah atau mengkonversi arus listrik searah menjadi arus bolakbalik. Inverter juga merupakan kebalikan dari converter atau adaptor, yang berfungsi mengkonversi tegangan bolak- 
balik / AC menjadi tegangan searah / DC. Saat ini telah ada beberapa topologi inverter yang tersedia, dimulai dari jenis inverter yang memiliki fungsi hanya dapat menghasilkan tegangan bolak balik saja atau push pull inverter hingga inverter dengan kemampuan hasil tegangan sinus murni tanpa efek harmonisasi. Inverter juga diklasifikasikan berdasarkan bagian fasa-nya, di antaranya satu fasa, tiga fasa, dan dengan multi fasa. [3]

Cara kerja sistem inverter ini adalah dengan cara mengubah input motor listrik arus bolak-balik / AC menjadi searah / DC, lalu kemudian di rubah lagi menjadi bolakbalik / AC tetapi dengan frekuensi yang di inginkan, sehingga dapat mengontrol kecepatan yang di butuhkan. Sebuah inverter biasanya digunakan untuk mengubah arus DC dari sumber seperti panel surya, baterai, dan lain sebagainya menjadi arus listrik AC yang umumnya terdapat pada barang elektronika rumah tangga.[4]

Ada beberapa teknik kendali yang bisa gunakan supaya inverter mampu menghasilkan sinyal sinusoidal. Inilah salah satu caranya, yakni dengan mengatur keterlambatan pada sudut penyalaan inverter ke tiap-tiap lengan. Metode yang paling sering digunakan yaitu modulasi lebar pulsa atau disebut juga PWM (Pulse Width Modulation). [4]

\section{4) Motor AC 3 Phasa}

Salah satu motor listrik yang umum digunakan dalam banyak aplikasi ialah motor induksi. Motor induksi merupakan salah satu mesin asinkronous (asynchronous motor) karena mesin ini beroperasi pada kecepatan di bawah kecepatan sinkron. Kecepatan sinkron sendiri ialah kecepatan rotasi medan magnetik pada mesin. Kecepatan sinkron ini dipengaruhi oleh frekuensi mesin dan banyaknya kutub pada mesin. Motor induksi selalu berputar dibawah kecepatan sinkron karena medan magnet yang terbangkitkan pada stator akan menghasilkan fluks pada rotor sehingga rotor tersebut dapat berputar. Namun fluks yang terbangkitkan pada rotor mengalami lagging dibandingkan fluks yang terbangkitkan pada stator sehingga kecepatan rotor tidak akan secepat kecepatan putaran medan magnet. [5]

Berdasarkan suplai input yang digunakan terdapat 2 jenis motor induksi, yaitu motor induksi 1 fasa dan motor induksi 3 fasa. Dari segi prinsip kerjanya sendiri, kedua jenis motor induksi tersebut memiliki prinsip kerja yang sama. Yang membedakan dari kedua motor induksi ini ialah motor induksi 1 fasa tidak dapat berputar tanpa bantuan putaran dari luar pada awal motor digunakan, sedangkan motor induksi 3 fasa dapat berputar sendiri tanpa bantuan gaya dari luar.

Sama seperti mesin-mesin listrik pada umumnya, motor 3 fasa memiliki 2 komponen penting, yaitu: stator dan rotor. [6]

\section{a. Komponen - Komponen Motor}

(1) Stator
Stator merupakan komponen yang tidak berputar pada mesin. Pada komponen ini dipasang stator winding berupa kumparan. Stator ini dihubungkan dengan suplai 3 fasa untuk memutar rotor. Stator sendiri memiliki 3 bagian penting:

\section{a) Frame}

Frame atau kerangka motor merupakan demensi pisik motor yang di buat standard agar pemakai mudah memasangnya. Dengan standard tertentu pembuat dan pemakai mudah menjual dan memilihnya. [6]

\section{b) Inti}

Inti stator merupakan tempat dimana stator winding dipasang. Inti stator bertugas untuk menghasilkan fluks. Fluks ini dihasilkan oleh kumparan pada stator winding dan dialiri oleh arus 3 fasa dari suplai 3 fasa. Untuk mencegah arus eddy yang besar pada stator winding umumnya inti stator dilapisi oleh lamina. Lamina sendiri terbuat oleh campuran besi silikon untuk mencegah rugi-rugi histerisis. Pada inti stator juga dipasang kutub-kutub magnet untuk menghasilkan fluks. [6]

\section{c) Winding}

Stator winding merupakan kumparan yang masingmasing kumparannya dihubungkan menjadi rangkaian star atau delta, tergantung dari bagaimana metode untuk memutar mesin yang digunakan dan jenis rotor yang digunakan. Untuk rotor jenis sarang tupai umumnya menggunakan rangkaian delta sedangkan rotor jenis slip ring bisa menggunakan salah satu dari keduanya. Stator winding dipasang pada sela-sela inti stator dan berfungsi untuk menghasilkan fluks. Stator winding juga dikenal sebagai kumparan medan. [6]

\section{(2) Rotor}

Rotor merupakan bagian yang dapat berputar dari motor. Rotor dihubungkan dengan beban yang akan diputar dengan sebuah shaft yang terpasang pada pusat rotor. Berdasarkan konstruksinya, rotor dibagi menjadi 2 macam: [6]

\section{a) Sarang tupai (Squirrel Cage)}

Rotor tipe ini memiliki bentuk seperti roda gear, berbentuk tabung dan diberi beberapa slot dipermukaannya. Slot ini tidak dibuat lurus namun sedikit miring untuk memperhalus kerja motor dan membuat konduktor pada rotor. Dikedua ujung rotor dipasang cincin alumunium. Umumnya rotor jenis ini terbuat dari alumunium atau tembaga. Rotor jenis ini sangat sering digunakan karena mudah dibuat dan dapat digunakan berapapun kutub pada stator. Rotor jenis ini dapat ditemui pada kipas angin dan blower pada printer. [6]

b) Slipring 
Rotor tipe ini memiliki rangkaian kumparan pada ujungnya dan memiliki sejumlah slip ring di belakangnya. Tiap kumparan terhubung dengan salah satu slip ring dimana masing-masing slip ring juga terhubung dengan rangkaian yang sama dengan rangkaian kumparannya. Jika rangkaian kumparannya berbentuk star maka rangkaian slip ring juga berbentuk star. Umumnya ditiap slip ring dipasang rheostat sehingga kecepatan putaran motor dapat diatur dengan mudah. Umumnya rotor jenis ini digunakan untuk beban-beban besar seperti untuk menggerakkan elevator atau lift. [6]

\section{b. Prinsip kerja motor AC 3 fasa}

Motor induksi 3 fasa bekerja jika memiliki sumber AC 3 fasa yang terhubung dengan stator pada motor. Karena stator terhubung dengan sumber AC maka arus dapat masuk ke stator melalui kumparan stator. Sekarang kita hanya melihat 1 kumparan stator saja. Sesuai hukum faraday bahwa apabila terdapat arus yang mengalir pada suatu kabel maka arus itu dapat menghasilkan fluks magnet pada kabel.

Setiap fasa dalam kumparan stator akan mengalami hal yang sama karena setiap fasa dialiri arus, namun besarnya fluks yang dihasilkan tidak sama di setiap waktu. Hal ini disebabkan besarnya arus yang berbeda-beda pada tiap fasa di tiap waktunya. Dimisalkan fasa-fasa ini diberi nama x, y, dan z. Ada kalanya arus pada fasa $x$ maksimum sehingga menghasilkan fluks maksimum dan arus fasa $y$ tidak mencapai makismum, dan ada kalanya arus pada fasa y maksimal sehingga menghasilkan fluks maksimum dan arus pada fasa $\mathrm{x}$ tidak mencapai maksimum. Hal ini mengakibatkan fluks yang dibangkitkan lebih cenderung pada fasa mana yang mengalami kondisi arus paling tinggi. Secara tidak langsung dapat dikatakan bahwa medan magnet yang dibangkitkan juga ikut "berputar" seiring waktu. Kecepatan putaran medan magnet ini disebut kecepatan sinkron. [7]

Akibat adanya fluks pada kumparan stator maka arus akan terinduksi pada rotor. Anggap rotor dibuat sedemikian sehingga arus dapat mengalir pada rotor (seperti rotor tipe squirrel cage). Akibat munculnya arus pada rotor dan adanya medan magnet pada stator maka rotor akan berputar mengikuti hukum lorentz. Kecepatan putaran rotor tidak akan pernah mencapai kecepatan sinkron atau lebih karena apabila kecepatan sinkron dan rotor sama, maka tidak ada arus yang terinduksi pada rotor sehingga tidak ada gaya yang terjadi pada rotor sesuai dengan hukum lorentz. Akibat tidak adanya gaya pada rotor maka rotor jadi melambat akibat gaya-gaya kecil (seperti gaya gesek dengan sumbu rotor atau pengaruh udara). Namun saat rotor melambat kecepatan sinkron dan kecepatan rotor jadi berbeda. Akibatnya pada rotor akan terinduksi arus sehingga rotor mendapatkan gaya berdasarkan hukum lorentz.

5) Arduino Uno ATMega328
Board arduino uno adalah Board Mikrokontroler (Development Board) menggunakan chip mikrokontroler ATmega328 yang fleksibel dan open-source, Software dan Hardware nya relatif mudah digunakan sehingga banyak dipakai oleh pemula sampai ahli. Untuk dapat digunakan board arduino uno dihubungkan ke komputer dengan menggunakan kabel USB atau dengan adaptor atau power supply 7-12 V DC. Arduino uno dapat digunakan untuk mendeteksi lingkungan dengan membaca data dari berbagai sensor, misalnya jarak, inframerah, suhu, cahaya, ultrasonik, tekanan, kelembaban dan lain lain. [8]

\section{6) MCB (Miniature Circuit Breaker)}

MCB adalah kependekan dari Miniature Circuit Breaker atau miniatur pemutus sirkuit. MCB adalah sebuah perangkat elektromekanikal yang dapat melindungi rangkaian listrik dari arus yang berlebihan dengan cara memutuskan arus tersebut secara otomatis saat melewati batas tertentu.

MCB memiliki fungsi memutus arus listrik secara otomatis, untuk melindungi rangkaian listrik ketika arus yang melewati MCB melebihi nilai yang ditentukan. Akan tetapi pada saat kondisi normal, MCB memiliki fungsi sebagai saklar yang dapat menghubungkan dan memutuskan aliran arus listrik secara manual.

Pada dasarnya MCB memiliki fungsi yang sama seperti sekering (FUSE), yakni memutus aliran arus listrik rangkaian saat terjadi kelebihan arus akibat hubung singkat (short circuit), atau akibat kelebihan beban (overload). Saat setelah arus listrik sudah normal, MCB dapat dinyalakan kembali, sedangkan sekering (FUSE) tidak.

\section{B. Software (Aduino IDE \& Sketch)}

Untuk mendukung hardware maka dibutuhkan software yang cocok untuk hardware tersebut. Salah satunya Arduino IDE \& Skecth yang merupakan aplikasi sebagai text editor untuk membuat, membuka, mengedit, dan juga mengvalidasi kode serta untuk di-upload ke board Arduino. Program yang digunakan pada Arduino disebut dengan istilah "sketch" yaitu file source code arduino dengan ekstensi .ino

\section{1) Arduino IDE}

Seperti teks editor pada umumnya yaitu memiliki fitur untuk cut / paste dan untuk find / replace teks. Pada bagian keterangan aplikasi memberikan pesan balik saat menyimpan dan mengekspor dan juga sebagai tempat menampilkan kesalahan. Konsol log menampilkan output teks dari Arduino Software (IDE), termasuk pesan kesalahan yang lengkap dan informasi lainnya. Pojok kanan bawah jendela menampilkan papan dikonfigurasi dan port serial. Tombol toolbar memungkinkan untuk memverifikasi dan meng-upload program, membuat, membuka, dan menyimpan sketch, dan membuka monitor serial.

2) Sketch Arduino 
Bahasa pemrograman yang digunakan pada Arduino ini berdasar pada bahasa $\mathrm{C} / \mathrm{C}++$. Program pada Arduino terbagi menjadi tiga bagian utama yaitu Structure, Values (berisi variable dan konstantata) dan yang terakhir function.

a. Structure

Struktur kode pada arduino yaitu berisi fungsi setup ( ) dan loop ( ).

\section{- $\operatorname{Setup~()~}$}

Fungsi ini dipanggil pertama kali ketika menjalankan sketch. digunakan sebagai tempat inisialisai variable, pin mode, penggunaan library dan lainnya. fungsi ini dijalankan sekali ketika board dinyalakan atau di reset.

\section{- $\quad$ Loop ( )}

Setelah membuat fungsi setup() sebagai tempat inisialisai variabel dan menetapkan nilai maka selanjutnya fungsi loop() seperti namanya fungsi ini akan melakukan perulangan berturu-turut, memungkinan program untuk mengubah dan menanggapi yang digunakan untuk mengontrol board Arduino

b. Values

Berisi variable atau konstanta sesuai dengan type data yang didukung oleh Arduino.

\section{- Function.}

Segmentasi kode ke fungsi memungkinkan programmer untuk membuat potongan-potongan modular kode yang melakukan tugas yang terdefinisi dan kemudian kembali ke asal kode dari mana fungsi itu "dipanggil". Umumnya menggunakan fungsi adalah ketika salah satu kebutuhan untuk melakukan tindakan yang sama beberapa kali dalam sebuah program.

\section{PeranCangan dan IMPLEMEntasi}

\section{A. Pengantar Perancangan dan Implementasi}

Bab ini membahas tentang implementasi perangkat keras dan perangkat lunak proyek. Prosedur kerja umum perangkat akan dijelaskan dalam diagram blok yang diikuti oleh flowchart keseluruhan sistem, kebutuhan komponen, desain perangkat keras dan dilanjutkan dengan implementasi perangkat lunak yang terdiri dari pengkodean program Arduino. Blok diagram perangkat seperti yang ditunjukkan pada Gambar 1 di bawah ini.

Diagram blok merupakan salah satu cara yang paling sederhana untuk menjelaskan cara kerja dari suatu sistem dan memudahkan untuk melokalisir kesalahan dari suatu sistem. Dengan diagram blok kita dapat menganalisa cara kerja rangkaian dan merancang hardware yang akan dibuat secara umum.

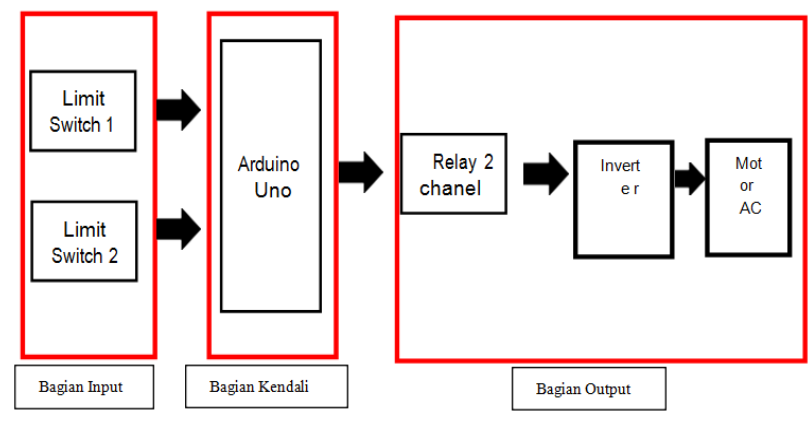

Gambar 1. Blok Diagram Perangkat

1) Limit Switch

Dari blok diagram rangkaian sistem di atas dapat dijelaskan fungsi masing-masing blok sebagai berikut:

a. Bagian Input

- $\quad$ Limit Switch 1

Mmm Sensor mekanis ini digunakan untuk membuka palang pintu, ketika pintu lift terbuka maka akan menyentuh limit switch 1 dan memerintahkan palang pintu untuk naik.

- $\quad$ Limit Switch 2

Sensor mekanis ini digunakan untuk menutup palang lift atau menurunkan palang lift, yang berfungsi ketika pintu lift bergerak menutup.

b. Bagian Pengendali (Arduino Uno)

Bagian blok ini menggunakan Arduino uno yang berfungsi memproses data yang diberikan oleh input dan mengolah menjadi suatu output sesuai dengan tujuan rancangan. Rancangan ini menggunakan arduino uno yang merupakan rangkaian komponen - komponen dengan komponen inti yaitu ATMega328P. Modul rangkaian ini menjadi otak dari sistem ini, dimana akan menerima input dari limit switch 1 dan 2 dan akan mengeluarkan output kepada relay 2 channel.

c. Bagian Output

- Relay 2 Channel

Piranti ini berfungsi sebagai saklar [ON/OFF] bagi inverter dan motor AC. Jika relay 1 mendapatkan perintah dari arduino maka akan memberikan sinyal LOW pada inverter dan motor sehingga akan motor akan bergerak mengangkat palang pintu, begitu pula sebaliknya.

- Inverter

Piranti ini berfungsi sebagai pengubah tegangan dari AC ke DC dan ke AC lagi yang akan memberikan perintah gerakan yang lebih baik kepada motor AC 3 phasa. Berdasarkan sinyal dari relay 1 dan 2 maka inverter menerjemahkan dengan mengubah tegangan yang berasal dari jala - jala menjadi sumber untuk motor dengan sinyal yang lebih baik. 
- Motor AC 3 Phasa

Motor AC ini berfungsi untuk menggerakan palang pintu dengan bergerak searah jarum jam yang artinya mengangkat palang pintu dan sebaliknya.

2) Limit Switch

Adapun spesifikasi alat dari rancangan ini, adalah sebagai berikut

1. Tinggi Palang Pintu $: 100 \mathrm{~cm}$

2. Panjang Palang Pintu $: 276 \mathrm{~cm}$

3. Lebar Mekanik $\quad: 16.5 \mathrm{~cm}$

4. Motor Penggerakan : Motor AC

5. Sensor Mekanik : Limit Switch [Omron]

6. Bahan dasar mekanis: Logiform

7. Sistem kendali: Arduino Uno \& Inverter

3) Limit Switch

Palang pintu memiliki 2 tipe instalasi, AC dan DC. $\mathrm{AC}$ akan menjadi sumber utama Motor AC, Inverter, dan MBC sedangkan DC merupakan sumber untuk sistem kontrol seperti Arduino uno, Relay dan Limit switch. Pemasangan sistem dari palang pintu lift sejauh 1.8 meter dari lift seperti Gambar 2 dibawah ini.



Gambar 2. Layout sistem palang pintu lift di lantai 2

Kita dapat melihat relay diaktifkan oleh sinyal dari Arduino yang didapatkan dari limit switch 1 ataupun 2 pada palang pintu berdasarkan Gambar 3. Untuk pengukuran, output dari relay dan sisi sekunder dari trafo potensial menuju ke pin digital dari Arduino UNO. Gambar diagram elektrik sistem lebih jelas berada di lampiran A.

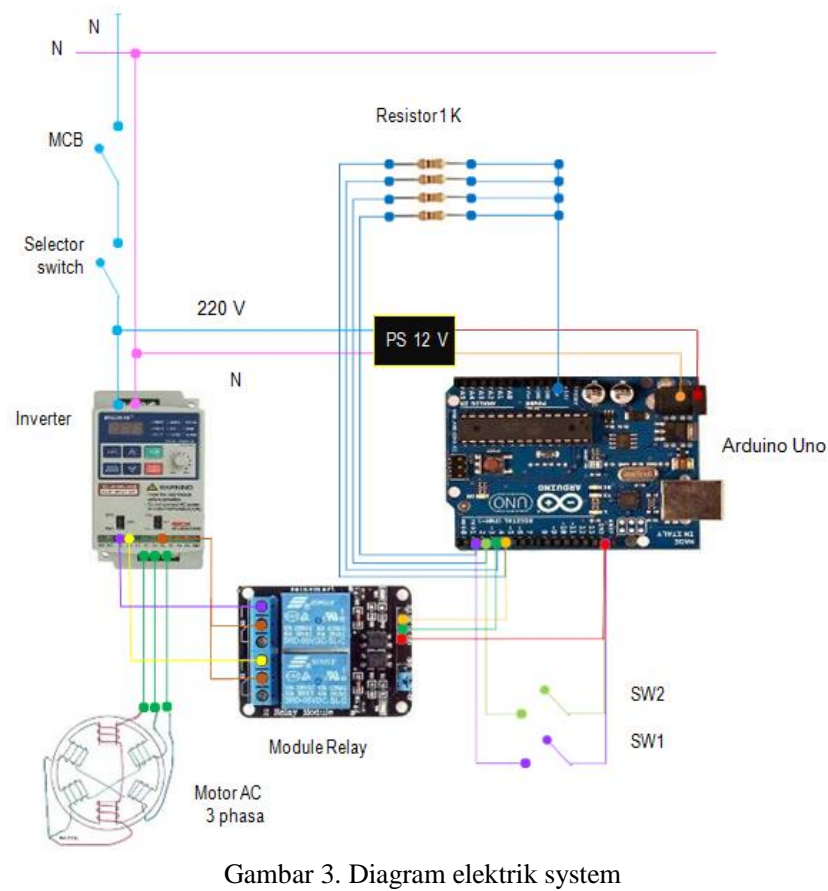

Pin - pin yang digunakan dari Arduino Uno sebagai pengendali sistem seperti tertera pada Tabel 2 dibawah ini.

Tabel 2. PIN-PIN DIGITAL ARDUINO UNO

\begin{tabular}{|c|cc|c|c|}
\hline No & \multicolumn{2}{|c|}{ No Pin } & Fungsi & Keterangan \\
\hline 1 & Digital Pin 01 & From limit switch 1 & Input 1 \\
\hline 2 & Digital Pin 02 & From limit switch 2 & Input 2 \\
\hline 3 & Digital Pin 03 & To Relay 1 (Up) & Output \\
\hline 4 & Digital Pin 04 & To Relay 2 (Down) & Output \\
\hline
\end{tabular}

\section{4) Metode Pengukuran}

Proses pengukuran dilakukan dengan melihat tegangan yang dihasilkan dari seluruh sistem. Berdasarkan spesfikasi setiap komponen maka akan dicheck nilai tegangan ketika limits switch memberikan perintah kepada Arduino.

5) Implementasi Software

Untuk mengimplementasikan program ke mikrokontroler, penulis menggunakan Arduino IDE 1.0.5. Program ini akan terdiri dari pengendali atas perintah yang akan direalisasi ke motor AC bergerak ke atas maupun ke bawah pada kuadran 4 dengan sudut $90^{\circ}$. 


\section{Journal of Electrical and Electronics Engineering}

Sketsa penuh dari program ini dapat dilihat di Lampiran B.

\section{B. Abbreviations and Acronyms}

Finally, complete content and organizational editing before formatting. Please take note of the following items when proofreading spelling and grammar:

\section{HASIL DAN ANALISA}

\section{A. Hasil Rancangan}

Alat ini didesain dengan mengimplementasikan desain yang sudah dijelaskan di Bab III. Desain ini dirancang sesuai dengan tujuannya, melindungi asset perusahaan dengan membuat sistem deteksi dini. Bab ini akan membahas hasil rancangan. Rancangan ini langsung diinstalasi di Dharma Electrindo Manufacturing Cirebon. Berikut beberapa Gambar 4 hasil instalasi rancangan $(4.1 \mathrm{~s} / \mathrm{d} 4.4)$.

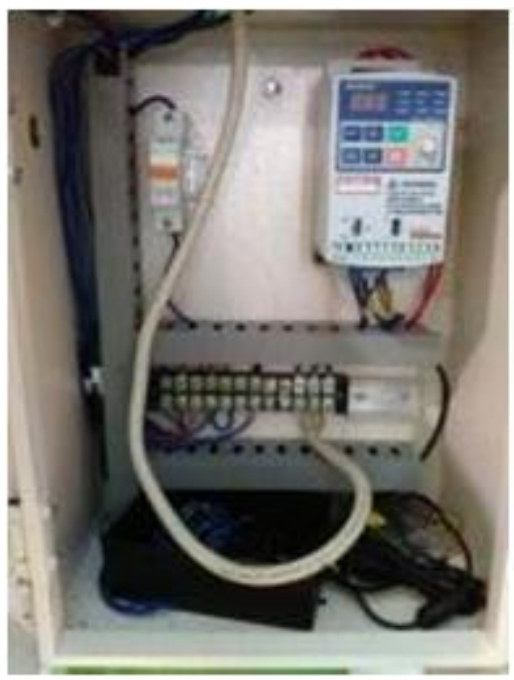

Gambar 4.1 Panel sistem palang pintu lift

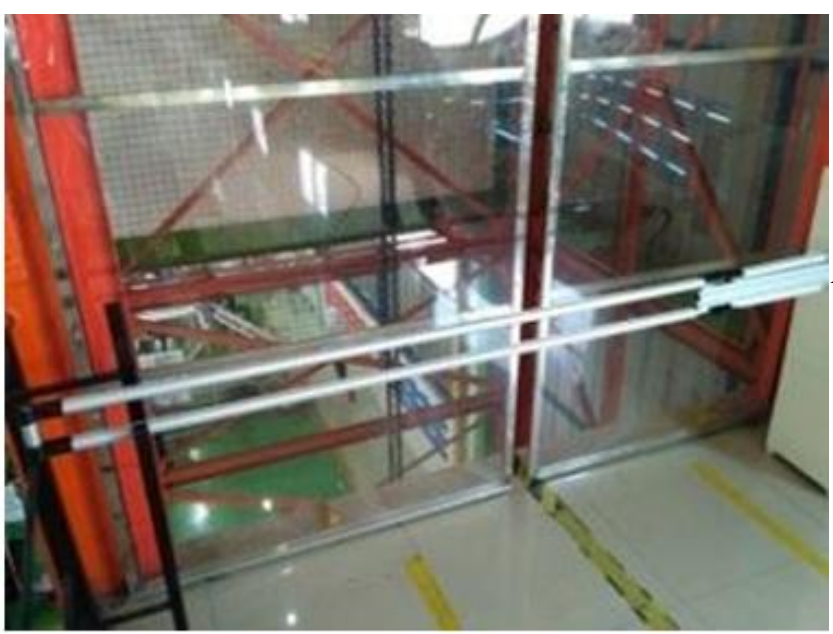

Gambar 4.2 Palang pintu lift lantai 2

Berdasarkan gambar 4.2. di atas terlihat palang pintu lift lantai 2 sudah terpasang sesuai dengan desain yang diinginkan. Desain ini diharapkan dapat mencegah terjatuhnya $\mathrm{AGV}$ dan menghalangi karya*an untuk terlalu dekat dengan pintu lift sesuai dengan gambar 4.3. dan gambar 4.4.

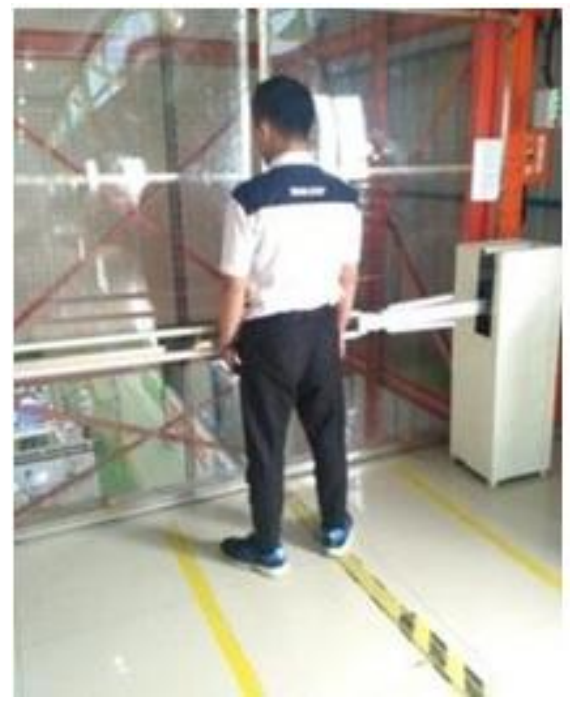

Gambar 4.3 Palang pintu lift lantai 2 (simulasi karyawan)

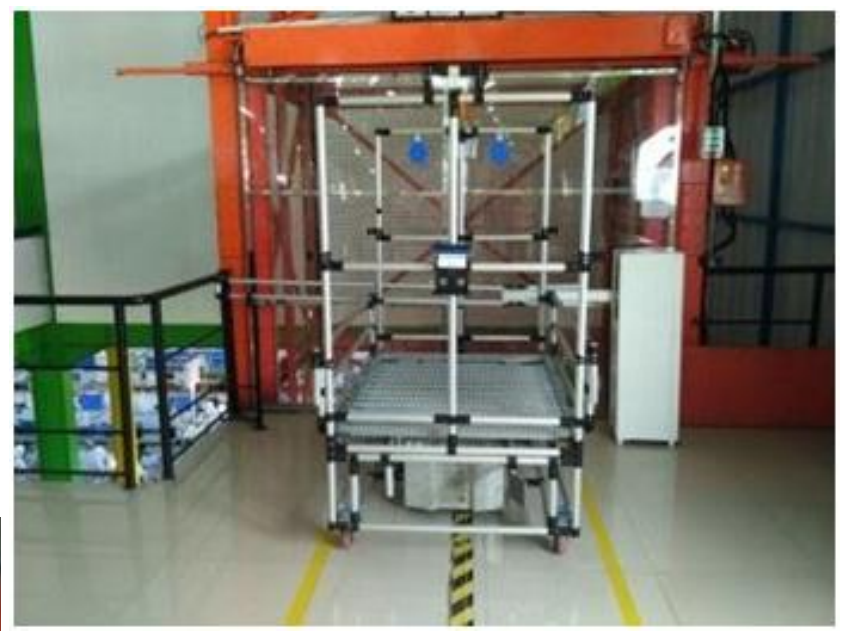

Gambar 4.4 Palang pintu lift lantai 2 (simulasi AGV) hadap depan

\section{B. Hasil Pengujian}

Hasil dilakukan dengan melakukan pengukuran berdasarkan teori deskriptif dengan mengambil data data hasil perancangan. Data di ambil dari setiap blok - blok sistem yang telah dibuat.

\section{1) Pengujian Catu Daya}

Pertama dilakukan untuk semua sistem dengan tegangan catu daya (Tabel 3) sebagai sumber dari keseluruhan sistem. 
Tabel 3. TEGANGAN CATU DAYA

\begin{tabular}{|c|c|c|}
\hline \multirow{2}{*}{ CATU DAYA } & \multicolumn{2}{|c|}{ TEGANGAN (V) } \\
\cline { 2 - 3 } & INPUT & OUTPUT \\
\hline Adaptor & $220 \mathrm{VAC}$ & $12 \mathrm{VDC}$ \\
\hline IC Regulator & $12 \mathrm{VDC}$ & $5 \mathrm{VDC}$ \\
\hline
\end{tabular}

Dengan sumber utama berasal dari jala - jala dengan besar tegangan $220 \mathrm{~V}$ AC yang kemudian diubah menjadi tegangan DC sebesar $12 \mathrm{~V}$ sebagai input Arduino. Tegangan dari Arduino kemudian akan berubah menjadi $5 \mathrm{~V}$ DC sebagai sumber tegangan untuk komponen yang disambungkan dengan Arduino.

\section{2) Pengujian Limit switch}

Limit switch digunakan untuk memberitahukan kepada arduino uno untuk memerintahkan palang pintu lift bergerak naik ataupun turun.

Adapun prosedur pengujian rangkaian limit switch adalah sebagai berikut :

1. Rangkaian limit switch dihubungkan dengan analog pin 01 dan analog pin 02

2. Mengukur perubahan tegangan output di setiap limit switch

3. Mencatat hasil pengujian pada Tabel 4.

TABel 4. PENGUJian PADA Limit Switch

\begin{tabular}{|c|c|c|c|}
\hline \multirow[b]{2}{*}{$\begin{array}{c}\text { KONDISI LIMIT } \\
\text { SWITCH (AKTIF } \\
\text { LOW) }\end{array}$} & \multicolumn{2}{|c|}{ TEGANGAN (V) } & \multirow[b]{2}{*}{ LOGIKA } \\
\hline & $\begin{array}{c}\text { LIMIT } \\
\text { SWITCH } 1 \\
(\text { PIN 01) }\end{array}$ & $\begin{array}{c}\text { LIMIT } \\
\text { SWITCH } 2 \\
\text { (PIN 02) }\end{array}$ & \\
\hline Ditekan & $\begin{array}{c}0 . \\
1\end{array}$ & 0.1 & 1 \\
\hline Tidak ditekan & $\begin{array}{l}4 . \\
9\end{array}$ & 4.9 & 0 \\
\hline
\end{tabular}

\section{3) Pengujian Arduino Uno}

Pengujian pada rangkaian arduino ini dilakukan dengan meng-check pin - pin pada Arduino yang mendapatkan sumber tegangan $12 \mathrm{~V}$ dan menghasilkan output tegangan $5 \mathrm{~V}$. Tabel 5 adalah hasil pengukuran pada setiap pin Arduino yang digunakan.

TABel 5. Pengujian Pada PIN ARduino Uno

\begin{tabular}{|c|c|}
\hline PIN & TEGANGAN (VOLT) \\
\hline 01 & 4,9 \\
\hline 02 & 4,8 \\
\hline 03 & 4,9 \\
\hline 04 & 4,9 \\
\hline
\end{tabular}

\section{4) Pengujian Relay 2 Channel}

Pengujian pada relay dilakukan dengan meng-check input-output pada relay 2 channel yang mendapatkan sumber input dari Arduino dengan tegangan $5 \mathrm{~V}$ DC sebagai sumber tegangan. Relay (aktif low) akan bekerja sesuai dengan logika yang didapat. Berdasarkan Tabel 6 terlihat hasil pengukuran relay 2 channel kurang lebih sama dengan spesifikasinya.

Tabel 6. Pengujian Pada Relay 2 Channel Dengan 2 KONDISI

\begin{tabular}{|l|c|l|}
\hline RELAY & TEGANGAN (V) & LOGIKA \\
\hline \multirow{2}{*}{ R1 } & 0.1 & 1 (aktif) \\
\cline { 2 - 3 } & 4.5 & 0 \\
\hline \multirow{2}{*}{ R2 } & 0.1 & 1 (aktif) \\
\cline { 2 - 3 } & 4.5 & 0 \\
\hline
\end{tabular}

\section{5) Pengujian Software}

Pada pengujian dan analisa software di bawah ini akan dibahas mengenai beberapa program dari alat ini. Dengan program yang terdapat pada lampiran B maka sesuai dengan hasil pengujian softare tidak mengalami gangguan ataupun ketidak sesuaian.

\section{6) Pengujian Palang Pintu Lift}

Untuk mengimplementasikan program ke mikrokontroler, Pengujian

Setelah melakukan pengujian terhadap arduino, limit switch dan relay, selanjutnya pengujian keseluruhan sistem. Pengujian hasil trial rancangan bertujuan melihat efektifitas dari desain yang telah dibuat pada Bab III. Hasil pengujian ini dilihat dari kondisi dari palang pintu lift pertahap sesuai dengan perbaikan yang dilakukan. Pengujian di ambil pada pukul 10.00 Wib bertepatan dengan jadwal AGV dari lantai 1 bergerak menuju lantai 2 .

- Percobaan 1

TABEL 7. HASIL PERCOBAAN KE - 1

\begin{tabular}{|c|c|c|c|c|c|}
\hline NO & PERINTAH & $\begin{array}{c}\text { STATUS } \\
\text { ALAT }\end{array}$ & HARAPAN & OBSERVASI & $\begin{array}{c}\text { KESIM } \\
\text { PULAN }\end{array}$ \\
\hline 1 & Close & DOWN & DOWN & DOWN & DOWN \\
\hline 2 & Open & DOWN UP & UP & ERROR & ERROR \\
\hline
\end{tabular}

Berdasarkan Tabel 7 terlihat hasil percobaan pertama dilakukan pada tanggal 06 Januari 2018. Ketika lift bergerak naik dari lantai 1 ke lantai 2 (lampu indikator berkedip \& sirene menyala). Pada saat lift berhenti di lantai 2, pintu lift terbuka dan menyentuh limit switch 1. Palang lift bergerak naik namun sebelum terbuka penuh, palang lift bergerak naik turun seirama dengan sirene.

Setelah ditelusuri kemungkinan penyebabnya adalah kuatnya medan magnet dari sistem lift. Oleh karena itu, rangkaian sistem palang lift yang semula digabung 
dengan panel listrik lantai 2, kemudian dipisahkan dan diletakkan pada panel tersendiri dengan ketebalan $0.4 \mathrm{~cm}$.

- Percobaan 2

TABel 8. Hasil PercobaAn Ke - 2

\begin{tabular}{|c|c|c|c|c|c|}
\hline NO & PERINTAH & $\begin{array}{c}\text { STATUS } \\
\text { ALAT }\end{array}$ & HARAPAN & OBSERVASI & $\begin{array}{c}\text { KESIMPUL } \\
\text { AN }\end{array}$ \\
\hline 1 & Close & DOWN & DOWN & DOWN & DOWN \\
\hline 2 & Open & DOWN/UP & UP & ERROR & ERROR \\
\hline
\end{tabular}

Hasil percobaan kedua terlihat pada Tabel 8 yang dilakukan di hari yang berbeda pada tanggal 13 Januari 2018, masih mengalami masalah yang sama, meski sudah dilakukan pemisahan panel sistem. Masih dengan penyebab pertama, kemudian dilakukan perbaikan dengan memindahkan panel sistem palang pintu lift yang semula 1,8 meter dari lift menjadi sejauh 7.8 meter dari lift. Untuk layout seperti Gambar 5 di bawah ini.

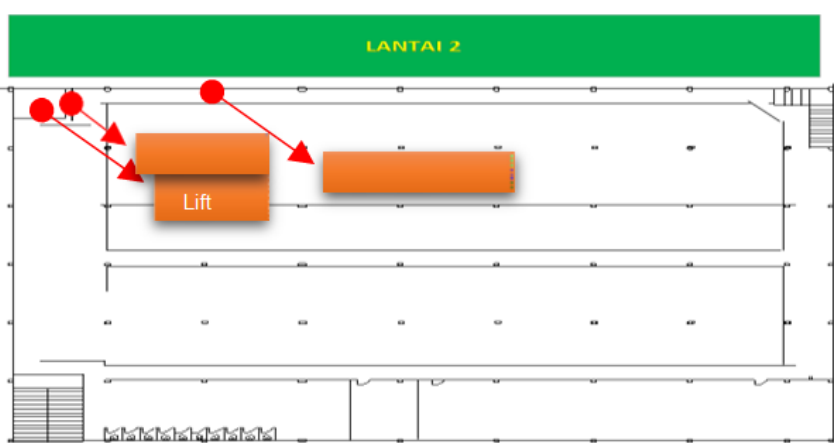

Gambar 5. Layout setelah pemindahan panel palang pintu lift

- Percobaan 3

TABel 9. Hasil PeRcobaAn KE - 3

\begin{tabular}{|c|c|c|c|c|c|}
\hline NO & PERINTAH & $\begin{array}{r}\text { STATUS } \\
\text { ALAT }\end{array}$ & HARAPAN & OBSERVASI & KESIMPULAN \\
\hline 1 & Close & DOWN & DOWN & DOWN & DOWN \\
\hline 2 & Open & UP & UP & UP & UP \\
\hline
\end{tabular}

Berdasarkan Tabel 9 terlihat hasil percobaan ketiga yang dilakukan pada tanggal 16 Januari 2018, tidak mengalami masalah atau sesuai dengan harapan. Demi menguji stabilitas dilakukan pula observasi pada hari selanjutnya.

- Percobaan 4

TABel 10. Hasil PercobaAn KE - 4

\begin{tabular}{|c|c|c|c|c|c|}
\hline NO & PERINTAH & $\begin{array}{r}\text { STATUS } \\
\text { ALAT }\end{array}$ & HARAPAN & OBSERVASI & KESIMPULAN \\
\hline 1 & Close & DOWN & DOWN & DOWN & DOWN \\
\hline
\end{tabular}

\begin{tabular}{|l|l|l|l|l|l|}
\hline 2 & Open & UP & UP & UP & UP \\
\hline
\end{tabular}

Berdasarkan Tabel 10, terlihat hasil dari percobaan pada tanggal 17 Januari 2018, juga tidak mengalami masalah.

C. Saving Yang Terjadi Setelah Instalasi Palang Pintu Lift

Sesuai dengan latar belakang masalah yang sudah dijabarkan pada Bab I dan pada Tabel 1 yang menunjukkan frekuensi kejadian masalah AGV menabrak pintu lift. Tercatat pada Tabel 11, dari 20 Januari 2018 sampai 23 Maret 2018 terjadi AGV menabrak pintu lift namun tidak ada kerusakan sehingga tidak ada kerugian sebesar 165.000 rupiah.

TABel 11. FreKuensi KeJAdian dan Kerugian AKibat Masalah AGV Setelah Instalasi Palang PINTU LIFT D LANTAI 2

\begin{tabular}{|c|c|c|c|c|}
\hline \multirow[t]{2}{*}{ NO } & \multirow[t]{2}{*}{ KEJADIAN } & $\begin{array}{c}\text { FREKUE } \\
\text { NS I } \\
\end{array}$ & \multirow[t]{2}{*}{ KERUGIAN } & \multirow{2}{*}{$\begin{array}{c}\text { TOTAL } \\
\text { KERUGIAN }\end{array}$} \\
\hline & & \begin{tabular}{|l|}
20 Jan $2018-$ \\
23 Maret 2018
\end{tabular} & & \\
\hline 1 & \begin{tabular}{|l} 
AGV tidak mau \\
masuk lift
\end{tabular} & 1 & Rp - & Rp - \\
\hline 2 & $\begin{array}{l}\text { AGV menabrak } \\
\text { pintu } \\
\text { lift lantai } 2\end{array}$ & 1 & Rp - & $\mathrm{Rp} \quad-$ \\
\hline 3 & $\begin{array}{l}\text { AGV menabrak } \\
\text { pintu } \\
\text { lift lantai } 3\end{array}$ & 2 & Rp165.000 & Rp330.000 \\
\hline 4 & $\begin{array}{l}\text { AGV tidak } \\
\text { berhenti di } \\
\text { stasion }\end{array}$ & 0 & Rp - & $\mathrm{Rp}$ \\
\hline 5 & Salah rute & 1 & $\mathrm{Rp}-$ & $\mathrm{Rp}$ \\
\hline
\end{tabular}

\section{Kelebihan dan Kelemahan Rancangan}

Kelebihan dari rancangan palang pintu lift di Dharma Electrindo Manufacturing ini adalah :

- Instalasi rancangan sesuai dengan harapan dengan mencegah terjadinya kerugian pada perusahaan

- Instalasi rancangan ini tujuan sesuai dengan tujuan yaitu mencegah rusaknya aset perusahaan (AGV)

Kelemahan dari rancangan palang pintu lift di Dharma Electrindo Manufacturing ini adalah :

- Proses pengukuran untuk setiap komponen tidak bisa dilakukan dikarenakan kurang lengkapnya fasilitas

- Rentannya sistem dikarenakan tidak stabilnya listrik di Cirebon. 


\section{KESIMPULAN DAN SARAN}

A. Kesimpulan

Dari hasil perancangan dan pengujian dari "Perancangan Deteksi Dini Pada Lift Barang Berbasis Arduino Uno di Dharma Electrindo Manufacturing" terdapat 2 kesimpulan yaitu :

1. Arduino Uno, Module Relay 2 Chanel, Limit Switch, Inverter dan Motor AC 3 fasa dapat diinstalasi dengan baik untuk mencegah terjadinya kehilangan asset perusahaan yaitu AGV dengan nilai sebesar kurang lebih 200.000.000 rupiah.

2. Terhitung dari minggu ke 4 Januari 2018 hingga 23 Maret 2018 menunjukkan tidak adanya kerugian yang diakibatkan kegagalan sistem sinkronisasi antara AGV dan lift barang yang sebelum deteksi dini dibuat telah mengeluarkan biaya 2.250.000 rupiah dan setelah pemasangan tidak ada biaya yang dikeluarkan atau 0 rupiah akibat AGV yang menabrak pintu lift.

\section{B. Saran}

Meskipun tujuan dari perancangan ini berhasil dicapai, desain dapat ditingkatkan untuk mencapai kinerja yang lebih baik. Beberapa rekomendasi untuk rancangan yang dihasilkan dari proyek akhir ini adalah penambahan alat penstabil atau pengatur keseimbangan listrik yang memungkinkan untuk menjaga kestabilan sistem pada palang pintu lift dikarenakan tidak stabilnya listrik di Cirebon.

\section{REFERENCES}

[1] Albert Paul Malvino, Ph.D., E.E, 2003, PrinsipPrinsip Elektronika, Jakarta: Salemba Teknika

[2] Rohmadi, 2013, Modul Relay 2 Channel Arduino. Diakses: 26 September 2017. [Online]. https://rohmadi.com/2013/12/09/modul-relay-2channel-arduino/

[3] Andri, H. (2012). Inverter Satu Fasa Sinkron Berbasis Digital Phase Locked Loop. Depok: Program Studi Magister Teknik Elektro Fakultas Teknik Elektro Universitas Indonesia.

[4] Anonim, 2013. Spesififkasi Inverter 3 Phase. Diakses: 14 Oktober 2018. [Online]. http://elektronika-dasar.web.id/inverter-3-phase/

[5] Rijono Yon, Drs. 1997. Dasar Tehnik Tenaga Listrik. Andi, Yogyakarta. Hal: 311

[6] Zuhal. 1991. Dasar Tenaga Listrik. ITB, Bandung. Hal: 68

[7] Muslimin, Zaenab. (2009). Pengontrolan Motor Induksi Tiga Fasa dengan Inverter Berbasis AT89S51. Makassar: Universitas Hasanudin

[8] Heryanto, Ary M. 2008. Pemrograman Bahasa C Untuk Mikrokontroler ATMEGA853. Yogyakarta: Andi Offset. 